INOBIS: Jurnal Inovasi Bisnis dan Manajemen Indonesia

Volume 04, Nomor 02, Maret 2021

Irawati, Adnan Rajak, Zulkifli, Rahmat Sabuhari

\title{
Pengaruh Komitmen Organisasional dan Pemberdayaan terhadap Kinerja Pegawai pada RSUD Dr. H. Chasan Boesoirie Ternate
}

\author{
Irawati \\ Mahasiswa Program Studi Manajemen Fakultas Ekonomi dan Bisnis Universitas Khairun \\ Adnan Rajak \\ Fakultas Ekonomi dan Bisnis Universitas Khairun \\ Zulkifli \\ Fakultas Ekonomi dan Bisnis Universitas Khairun \\ Rahmat Sabuhari \\ Fakultas Ekonomi dan Bisnis Universitas Khairun \\ * rahmat.sabuhari@unkhair.ac.id
}

\begin{abstract}
Abstrak
Setiap pemimpin diharapkan mampu mengarahkan pegawai untuk mencapai visi dan misi organisasi melalui komitmen dan pemberdayaan pegawai. Oleh karena itu peneliti ingin mengetahui dan menganalisis pengaruh langsung secara parsial komitmen organisasional dan pemberdayaan terhadap kinerja pegawai; dan pengaruh langsung secara simultan pada RSUD Dr. H. Chasan Boesoirie Ternate. Alat uji yang digunakan adalah analisis regresi linear berganda dengan menggunakan statistical package for social scientists (SPSS) sebagai alat uji statistik. Responden yang dijadikan sampel sebagai unit analisis sebanyak 84 pegawai. Hasil penelitian menunjukan bahwa: secara parsial komitmen organisasi dan pemberdayaa memiliki pengaruh yang signifikan terhadap kinerja pegawai; secara simultan komitmen organisasi dan pemberdayaan memiliki pengaruh yang signifikan terhadap kinerja pegawai. Atasan langsung pegawai perlu membangun keharmonisan hubungan kerja dalam melakukan pengawasan di tempat kerja; memberikan kesempatan untuk memanfaatkan waktu luang untuk melakukan aktivitas lain dalam bekerja; mengevaluasi dan menerapkan disiplin kerja pegawai secara adil.
\end{abstract}

Kata Kunci: Komitmen Organisasional, Pemberdayaan, dan Kinerja Pegawai.

\section{Pendahuluan}

Pegawai sebagai sumberdaya utama dan penggerak organisasi dituntut untuk bekerja lebih baik agar tujuan organisasi dapat tercapai. Untuk mencapai tujuan yang telah ditetapkan maka pimpinan diharapkan mampu memotivasi pegawai dalam bekerja dan memahami faktorfaktor yang ikut mempengaruhinya. Karena, keberhasilan suatu organisasi dalam mencapai tujuannya tidak terlepas dari keberhasilan pegawai (sumberdaya manusia) yang dimilikinya. Dengan kata lain, setiap pemimpinan diharapkan mampu mengarahkan sumberdaya manusia yang dimilikinya agar berkomitmen terhadap organisasi serta melakukan pemberdayaan pegawai demi terwujudnya peningkatan kinerja pegawai di dalam organisasi yang dipimpinnya. Kinerja pegawai merupakan tingkat pencapaian target yang dilakukan oleh seorang pegawai untuk memenuhi misi organisasi di tempat kerja (Cascio, 2006; Sabuhari \& Irawanto, 2020).

Berkaitan dengan uraian di atas, RSUD Dr. H. Chasan Boesoirie Ternate juga memerlukan sumberdaya manusia yang berkompeten dan memiliki komitmen organisasionalnya. Sumberdaya manusia memiliki efek secara langsung dalam memberikan 
kontribusi terhadap tercapainya visi, misi, dan tujuan RSUD Dr. H. Chasan Boesoirie Ternate. Untuk merealisasikan visi dan misi tersebut, tentunya membutuhkan ketersediaan berbagai sumberdaya yang memiliki kompetensi dibidangnya masing-masing. Artinya sumberdaya manusia merupakan modal untuk mencapai tujuan dapat meningktakan kinerja pegawai yang secara langsung mempengaruhi kesuksesan organisasi RSUD. RSUD Dr. H. Chasan Boesoirie Ternate adalah milik pemerintah dan sebagian besar pegawainya adalah pegawai negeri sipil, maka penilaian kinerjanya berdasarkan pada Peraturan Pemerintah Nomor 46 Tahun 2011 Tentang Penilaian Prestasi Kerja PNS. Berkaitan dengan hal ini, maka untuk melihat perkembangan capaian sasaran kerja (kinerja) PNS RSUD disajikan pada tabel 1. di bawah ini:

Tabel 1. Rekapitulasi Hasil Penilaian Capaian Sasaran Kerja PNS yang Tidak Menduduki Jabatan Struktural di Bagian Manajemen RSUD Dr. H. Chasan Boesoirie Ternate

\begin{tabular}{|c|l|c|c|c|c|}
\hline No. & Unit Kerja & $\begin{array}{c}\text { Jlh } \\
\text { PNS }\end{array}$ & $\begin{array}{c}\text { Rata-Rata } \\
\text { Nilai } \\
\text { Capaian } \\
\text { PNS }\end{array}$ & $\begin{array}{c}\text { \% Nilai } \\
\text { Capaian } \\
\text { PNS }\end{array}$ & Kategori \\
\hline 1 & Kepegawaian & 6 & 84,00 & 7,21 & Baik \\
\hline 2 & Keuangan & 14 & 83,20 & 7,14 & Baik \\
\hline 3 & Umum Dan Perlengkapan & 14 & 82,64 & 7,09 & Baik \\
\hline 4 & IPS & 1 & 82,35 & 7,07 & Baik \\
\hline 5 & Komite PPI & 2 & 84,00 & 7,21 & Baik \\
\hline 6 & Instalasi Diklat & 1 & 83,00 & 7,12 & Baik \\
\hline 7 & Perencanaan & 5 & 83,25 & 7,14 & Baik \\
\hline 8 & Promosi & 5 & 83,24 & 7,14 & Baik \\
\hline 7 & Verifikator BPJS & 7 & 83,74 & 7,18 & Baik \\
\hline 8 & Rekam Medik & 14 & 83,63 & 7,18 & Baik \\
\hline 9 & Loket Pendaftaran & 17 & 83,02 & 7,12 & Baik \\
\hline 10 & Server & 4 & 83,25 & 7,14 & Baik \\
\hline 11 & Pelayanan Medik & 1 & 83,00 & 7,12 & Baik \\
\hline 12 & Keperawatan & 2 & 83,25 & 7,14 & Baik \\
\hline
\end{tabular}

Sumber: Kepegawaian RSUD, Juni 2020

Tabel 1. menunjukkan bahwa hasil penilaian capaian Sasaran Kerja Pegawai (SKP) menunjukan bahwa rata-rata nilai capaian SKP di berbagai Unit kerja bernilai baik $(83,26)$ atau rata-rata $\pm 7,14 \%$. Yang mana berdasarkan rata-rata nilai capaian PNS katagori baik berada pada rentang skoring $>76,00-90,00$. Hal ini juga mengindikasikan bahwa tujuan atau VisiMisi RSUD Dr. H. Chasan Boeosirie Ternate dipengaruhi oleh kinerja pegawai negeri sipil (Sasaran Kerja Pegawai) yang tidak menduduki jabatan struktural.

Uraian fenomena kinerja tersebut di atas memberikan gambaran bahwa apabila kinerja para pegawai baik, maka kinerja organisasi akan meningkat. Sebaliknya apabila kinerja pegawai buruk, maka dapat menyebabkan menurunnya kinerja organisasi. Karena itu, perlu untuk memahami tentang faktor-faktor apa saja yang mempengaruhi kinerja pegawai. Kinerja pegawai secara teori dipengaruhi oleh beberapa faktor diantaranya adalah komitment organisasional dan pemberdayaan pegawai. Walaupun kinerja pegawai RSUD sebagaimana pada Tabel 1. tersebut di atas berada pada kategori baik, pengamatan penulis dilapangan menunjukan bahwa, masih adanya pegawai yang belum memahami sistem penilaian kinerja yang tertuang dalam Peraturan Pemerintah Nomor 46 Tahun 2011 tentang Penilaian Prestasi Kerja PNS, pegawai belum mampu membuat rencana kerja sesuai dengan tupoksi, dan pegawai 
belum mentaati waktu kerja sesuai dengan jam kerja yang telah ditentukan. Oleh karena itu, peneliti ingin mengkaji lebih mendalam pada variabel komitmen organisasi dan pemberdayaan (empowerment).

Menurut McShane \& Glinow (2008): komitmen atau loyalitas seorang karyawan pada suatu organisasi, bila mana emosional, identifikasi, dan keterlibatannya tetap pada keinginan atau tujuan-tujuan organisasi. Komitmen organisasi juga merupakan loyalitas dan keterikatan karyawan dengan organisasi (Daft, 2006). Hasil penelitian yang menunjukan bahwa komitmen organisasi yang terdiri dari komitmen afektif, normatif, dan komitmen kontinyu berpengaruh positif dan signifikan terhadap kinerja pegawai (employee performance) pada organisasi sektor publik dan sektor privat (Susanti \& Palupiningdyah, 2016; Manery, Lengkong, \& Saerang, 2018; Latief, Syardiansah, \& Muhammad, 2019; dan Ramli \& Siti, 2020).

Selain komitmen organisasional yang mempengaruhi kinerja pegawai terdapat juga variabel pemberdayaan juga ikut mempengaruhi kinerja pegawai. Secara konseptual menurut Luthans (2012) bahwa pencarian dan pengakuan kekuatan karyawan dalam organisasi dengan asumsi bahwa orang memiliki kekayaan pengetahuan dan memiliki motivasi internal. Artinya bahwa, pemberdayaan merupakan upaya pimpinan atau manajemen organsiasi untuk mensinergikan pengetahuan karyawan dan keinginan dalam rangka mencapai tujuan organisasi. Pemberdayaan (empowerment) dapat dilihat berdasarkan: sense of meaning, sense of competence, sense of determination, dan sense of impact. Dengan demikian, karyawan yang diberdayakan dengan baik akan mampu menghasilkan kinerja yang sesuai dengan tujuan organsiasi. Hal ini sesuai dengan hasil penelitian yang menunjukan bahwa pemberdayaan (empowerment) berpengaruh positif signifikan terhadap kinerja karyawan (Irfandi, Yonathan, \& Dirga, 2017). Sedangkan hasil penelitian (Bose, 2018) dan (Chauhan, 2017) menunjukan bahwa, pemberdayaan (empowerment) tidak memiliki hubungan positif signifikan terhadap kinerja karyawan.

Berdasarkan pada uraian fenomena riset di atas, masih terdapat perbedaan hasil penelitian maka dipandang penting untuk meneliti dan mengkaji lebih mendalam dan komprehensif tentang:

1. Apakah komitmen organisasional berpengaruh positif dan signifikan terhadap kinerja pegawai?

2. Apakah pemberdayaan pegawai berpengaruh positif dan signifikan terhadap kinerja pegawai?

3. Apakah komitmen organisasional dan pemberdayaan secara simultan berpengaruh positif terhadap kinerja pegawai?

\section{Landasan Teori dan Pengembangan Hipotesis}

\section{Pengaruh Komitmen Organisasional Terhadap Kinerja Pegawai}

Menurut Mangkunegara (2009) bahwa kinerja karyawan (prestasi kerja) adalah hasil kerja secara kualitas dan kuantitas yang dicapai oleh seseorang karyawan dalam melaksanakan tugasnya sesuai dengan tanggung jawab yang diberikan kepadanya. Campbel (1990) tidak hanya melihat kinerja sebagai suatu hasil, tetapi kinerja juga merupakan perilaku yang perlu dibedakan, karena hasil dan perilaku kerja dapat dipengaruhi oleh faktor-faktor sistem organisasi. Sedangkan komitmen organisasional menurut George \& Jones (2005) adalah berhubungan dengan perasaan dan keyakinan tentang pekerjaan organisasi secara keseluruhan. Berdasarkan definisi kinerja dan komitmen organisasional tersebut, menunjukan bahwa kinerja karyawan didalam organisasi ditentukan oleh kualitas dan kuantitas pekerjaan, yang mana kedua faktor ini memerlukan sikap dan perilaku karyawan di tempat kerja termasuk 
didalamnya adalah komitmen pegawai terhadap organisasional. Artinya, sikap dan perilaku khususnya terkait dengan keinginan dan keyakinan seorang karyawan sangat diperlukan untuk menghasilkan kinerja terbaik untuk individu, kelompok, dan organisasi.

Terkait dengan uraian di atas, komitmen organisasional harus diketahui melalui suatu evaluasi kerja dari pimpinan yang didapat dilakukan dengan mengukur komitmen pegawai. Dimensi yang menjadi ukuran komitmen organisasional itu sendiri terdiri dari: komitmen afektif, kontinyu, dan komitmen normatif. Faktor atau dimensi komitmen tersebut merupakan faktor-faktor yang dapat menciptakan atau menghasilkan karyawan untuk bekerja sesuai dengan keinginan unit, kelompok, maupun organisasi. Dengan kata lain, faktor-faktor komitmen organisasional dapat mempengaruhi sikap dan perilaku karyawan dimana para karyawan akan konsisten melaksanakan tugas dan fungsinya sebagai karyawan dan selalu menunjukan hasil kerja (performance) yang memiliki nilai dan manfaat bagi individu, kelompok, dan organisasi.

Berdasarkan uraian di atas, menunjukan bahwa komitmen organisasional merupakan variabel independen yang mampu mempengaruhi secara langsung kinerja pegawai di dalam organisasional. Hal ini dapat dilihat berdasarkan penelitian terdahulu yang dilakukan oleh: (Adiftiya, 2014; Melizawati, 2015; Susanti \& Palupiningdyah, 2016; Manery et al., 2018; dan Paramita, Erna, Prihatin, Lumbanraja, \& Yeni, 2020) hasil penelitiannya menunjukan bahwa komitmen organisasional yang meliputi: komitmen efektif (affective commitment), komitmen kontinyu (continuance commitment), dan komitmen normatif (normative commitment) berpengaruh positif terhadap kinerja karyawan. Berdasarkan uraian di atas, maka dapat dirumuskan hipotesis sebagai berikut:

\section{$\mathrm{H}_{1}$. Komitmen organisasional berpengaruh positif dan signifikan terhadap kinerja pegawai.}

\section{Pengaruh Pemberdayaan Terhadap Kinerja Pegawai}

Secara teoretik, komitmen organisasional selain berpengaruh langsung terhadap kinerja karyawan, variabel lain yakni pemberdayaan (empowerment) juga memiliki pengaruh langsung terhadap kinerja karyawan. Menurut Ivancevich, Robert, \& Matteson (2011) pemberdayaan merupakan proses organisasi yang berusaha mendorong dan/atau membantu individual dan kelompok untuk memiliki kemampuan dalam membuat/mengambil keputusan yang dapat mempengaruhi lingkungan kerja mereka (anggota organisasi). Sedangkan menurut Luthans (2012): pemberdayaan (empowerment) adalah otoritas dalam membuat keputusan di area tanggung jawab anggota organisasi tanpa meminta persetujuan orang lain. Berdasarkan pendapat tersebut, maka dapat dijelaskan bahwa para karyawan perlu diberdayakan oleh organisasi atau pimpinan sehingga mereka dapat meningkatkan kemampuannya dan mampu mengambil keputusan terkait dengan pekerjaan yang telah ditentukan oleh organisasi. Artinya, dengan adanya pemberdayaan, karyawan akan mampu menghasilkan suatu hasil kerja yang sesuai dengan keinginan organisasi atau mampu menghasilkan kinerja tugas yang maksimal.

Faktor perberdayaan karyawan yang dapat dilakukan melalui (1) self determination: pemberdayaan karyawan terkait dengan perasaan bahwa mereka memiliki kebebasan, independensi, dan kewenangan dalam melakukan aktivitas kerja; (2) meaning: pemberdayaan karyawan terkait dengan perhatian anggota organisasi tentang pekerjaan dan kepercayaan mereka adalah penting; (3) competence: pemberdayaan terkait dengan keyakinan mereka tentang kemampuan dan keahlian yang dimiliki untuk pertumbuhan/pengembangan terkait dengan tantangan baru; dan (4) impact: pemberdayaan karyawan dimana anggota organisasi aktif didalam organsisasi berkaitan dengan tindakan dan pengambilan keputusan individu yang memiliki pengaruh terhadap kesuksesan organisasi. Faktor-faktor pemberdayaan tersebut 
secara teori mampu memberikan dorongan kepada karyawan untuk menghasilkan pekerjaan yang memiliki kualitas, dan kuantitas kerja yang lebih baik dari sebelumnya, serta mampu menciptakan sikap dan perilaku kerja yang bermanfaat bagi anggota organisasi dan organisasi itu sendiri.

Uraian di atas mengandung arti bahwa, pemberdayaan karyawan yang meliputi: self determination, meaning, comptence, dan impact akan mendorong karyawan memiliki kinerja tinggi. Dengan kata lain, kinerja karyawan meningkat bilamana karyawan diberdayakan oleh organisasi. Hal ini secara empiris telah dibuktikan dalam penelitian terdahulu yang menunjukan bahwa pemberdayaan berpengaruh positif dan signifikan terhadap kinerja karyawan/pegawai (Meyerson \& Dewenttinck 2012; Irfandi et al. 2017; Fauzi 2019; Kumar \& Sajld 2019). Dengan demikian maka dapat disrumuskan hipotesis sebagai berikut:

\section{$\mathrm{H}_{2}$. Pemberdayaan pegawai berpengaruh positif dan signifikan terhadap kinerja pegawai.}

$\mathrm{H}_{3}$. Komitmen organisasional dan pemberdayaan secara simultan berpengaruh positif terhadap kinerja pegawai.

Berdasarkan uraian teori dan pengembangan hipotesis maka dapat dibuat gambar alur hipotesis dalam suatu kerangka konsep penelitian sebagai berikut:

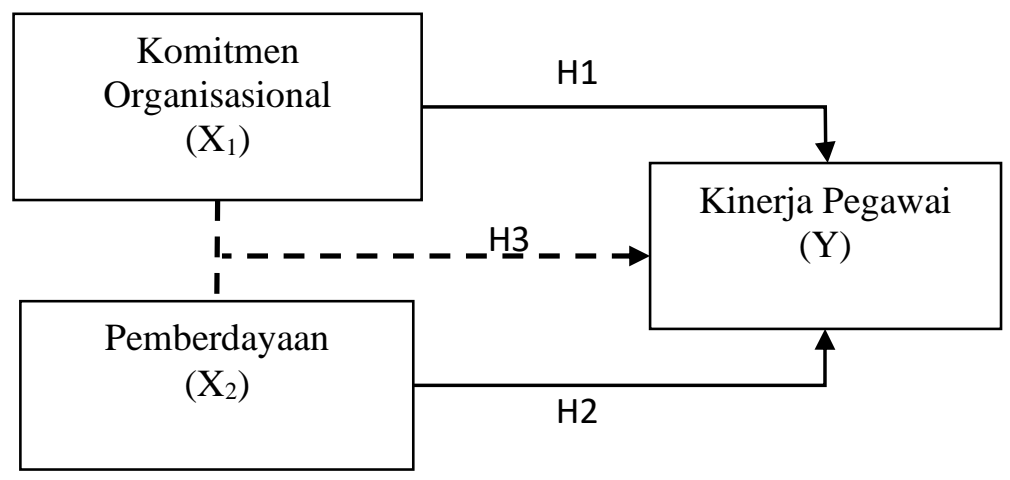

Gambar 1. Kerangka konsep penelitian

\section{Metode Penelitian}

Populasi dan sampel dalam penelitian ini adalah Pegawai Negeri Sipil (PNS) dilingkungan RSUD Dr. H. Chasan Boeosirie Ternate. Jumlah populasi target secara keseluruhan adalah sebanyak 543 PNS. Ukuran sampel secara keseluruhan dapat ditentukan dengan menggunakan rumus dari Taro Yamane atau Slovin (Riduwan \& Kuncoro, 2014) yakni sebanyak 84 orang sebagai responden penelitian. Kuesioner digunakan untuk mengumpulkan data persepsi responden yang terkait dengan variabel yang diteliti.Untuk menguji pengaruh antara variabel bebas dan terikat yakni pengaruh komitmen organisasional, dan pemberdayaan terhadap kinerja RSUD Dr. H. Chasan Boesoirie Ternate secara parsial maupun simultan, maka alat uji yang digunakan adalah analisis regresi linear berganda (multiple regression) dengan menggunakan SPSS sebagai alat uji statistik. Model persamaan regresi linear berganda adalah:

Keterangan:

$$
\mathbf{Y}=\alpha+\boldsymbol{\beta}_{1} \mathbf{X}_{1}+\boldsymbol{\beta}_{2} \mathbf{X}_{2}
$$

$\mathrm{Y}=$ Variabel terikat (kinerja pegawai)

$\alpha \quad=$ Nilai konstanta

$\beta_{1}, \beta_{2}=$ Koefisien determinasi 
$\mathrm{X}_{1} \quad=$ Komitmen organisasional

$\mathrm{X}_{2} \quad=$ pemberdayaan

Untuk menguji apakah instrumen yang digunakan memenuhi syarat-syarat alat ukur yang baik, maka digunakan uji validitas dan uji reliabilitas data yang bersumber dari 84 responden $(\mathrm{n}=84)$ dan hasilnya dianalisis menggunakan Perason Correlation pada taraf signifikan 5\%. Hasil uji validitas menunjukkan bahwa variabel komitemen organisasional terdiri dari 10 item, variabel pemberdayaan 8 item, dan variabel kinerja pegawai 14 item pernyataan yang valid dan 2 item dinyatakan tidak valid. Masing-masing pernyataan yang valid memiliki nilai Perason Correlation ( $r$ hitung) lebih besar dari nilai $r_{\text {tabel }}(0.220)$ dan nilai Signifikan lebih besar dari $\alpha$ $(0,05)$ yang berarti bahwa pernyataan yang digunakan pada ketiga variabel yang dianalisis adalah valid, dan layak digunakan sebagai instrumen penelitian. Selanjutnya hasil uji reliabilitas menunjukkan bahwa instrumen yang digunakan telah memenuhi syarat reliabilitas yaitu nilai Cronbach alpha pada variabel komitmen organisasional $=0$, 747, variabel pemberdayaan $=0,741$, dan variabel kinerja pegawai $=0,757$. Selanjutnya adalah uji analisis yang digunakan sebelum melakukan analisis Regresi Linear Berganda dengan menggunakan statistical package for social scientists (SPSS) sebagai alat uji statistik, maka terlebih dahulu dilakukan pengujian persyaratan analisis dengan melakukan uji asumsi klasik regresi. Dan pada bagian akhir adalah uji statistic yaitu uji t dan uji $\mathrm{f}$.

Uji asumsi klasik terdiri dari uji normalitas, uji multikolinieritas, dan uji heteroskedastisitas. Hasil uji normalitas dengan menggunakan probability plot menunjukkan bahwa variabel komitmen organisasional, pemberdayaan, dan kinerja pegawai berdistribusi normal. Hal ini karena, titik-titik data menyebar disekitar garis diagonal dan mengikuti garis diagonal yang dapat dilihat pada Gambar 2 berikut.



Gambar 2. Hasil Uji Normalitas Probility Plot

Uji multikolinieritas diperoleh value inflation factor (VIF) oleh variabel komitmen organisasional dan pemberdayaan sebesar 1.449. Karena nilai VIF kurang dari 5, maka dapat disimpulkan bahwa pada model regresi tidak ditemukan adanya masalah multikolinearitas. Uji heteroskedastisitas digunakan untuk mengetahui ada atau tidaknya ketidaksamaan varian dari residual pada model regresi. Hasil uji dengan menggunakan SPSS dapat dilihat pada Gambar 3. Terlihat bahwa tidak ada pola yang jelas serta titik-titik tersebut menyebar di atas dan di bawah angka 0 pada sumbu Y. Hal ini menunjukkan bahwa data dalam penelitian ini tidak terjadi heteroskedastisitas. 


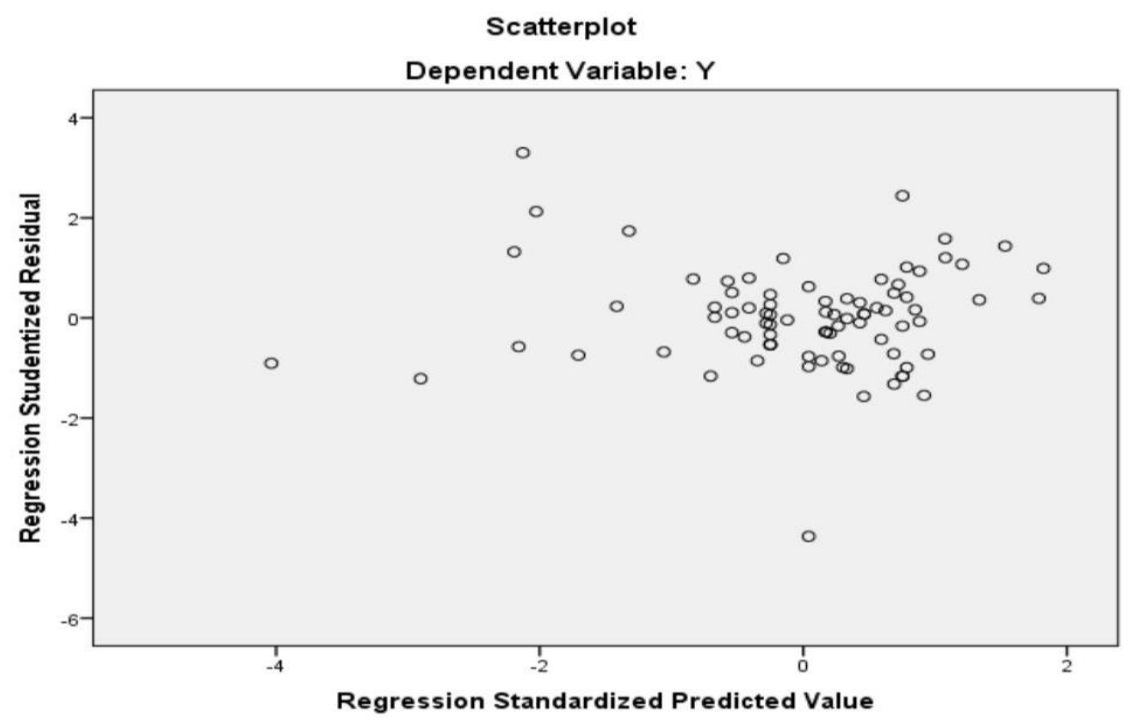

Gambar 3. Hasil Uji Heteroskedastisitas Scatterplot

\section{Hasil Penelitian}

Komposisi responden berdasarkan aspek jenis kelamin menunjukkan bahwa responden pria merupakan responden yang lebih dominan yaitu $60 \%$ dari total 84 responden yang. Hal ini menunjukkan bahwa sebagian besar responden pada RSUD Dr. H. Chasan Boeosirie Ternate adalah jenis kelamin pria. Komposisi menurut usia menunjukkan bahwa responden berusia 31 s.d 42 tahun adalah yang terbesar yaitu 57\% dari total 84 responden. Hal ini karena usia pegawai 31-42 adalah usia produktif. Selanjutnya menurut usia menunjukkan bahwa responden lulusan Strata 1 merupakan responden mayoritas yaitu $48 \%$ dari total 84 responden yang berpartisipasi dalam penelitian ini.

Penelitian ini menggunakan uji t, untuk menguji variabel bebas secara parsial yaitu komitmen organisasional, dan pemberdayaan ada atau tidaknya pengaruh terhadap variabel terikat yaitu kinerja pegawai. Adapun hasil uji regresi parsial (t) sebagai berikut:

Tabel 2. Hasil Pengujian Regresi Linear Berganda Pengaruh Variabel X1 dan X2 Terhadap Kinerja Pegawai

Coefficients $^{\text {a }}$

\begin{tabular}{|l|r|r|r|r|r|}
\hline \multirow{2}{*}{ Model } & \multicolumn{2}{|c|}{$\begin{array}{c}\text { Unstandardized } \\
\text { Coefficients }\end{array}$} & $\begin{array}{c}\text { Standardized } \\
\text { Coefficients }\end{array}$ & \multirow{2}{*}{$t$} & \multirow{2}{*}{ Sig. } \\
\cline { 2 - 4 } & \multicolumn{1}{|c|}{$B$} & Std. Error & \multicolumn{1}{|c|}{ Beta } & & \\
\hline (Constant) & 11.082 & 5.344 & & 2.074 & .041 \\
X1 & .535 & .155 & .356 & 3.456 & .001 \\
X2 & .666 & .187 & .367 & 3.566 & .001 \\
\hline
\end{tabular}

a. Dependent Variable: Kinerja pegawai (Y)

Sumber: Data diolah, 2021

Berdasarkan hasil analisis regresi linear berganda pada Tabel 2. menunjukan bahwa, variabel X1 memiliki nilai t hitung 3,45 6 lebih besar dari nilai t tabel sebesar 1,99. Sedangkan nilai signifikansi sebesar 0,001 lebih kecil dari $\alpha=5 \%(0,05)$. Karena $t_{\text {hitung }}>t_{\text {tabel, }}$ maka $H_{o}$ ditolak dan $\mathrm{H}_{\mathrm{a}}$ diterima. Dengan demikian komitmen organisasi berpengaruh positif dan signifikan secara parsial terhadap kinerja pegawai. Variabel X2 memiliki nilai t hitung 3,566 


\section{Irawati, Adnan Rajak, Zulkifli, Rahmat Sabuhari}

lebih besar dari nilai t tabel sebesar 1,99. Sedangkan nilai signifikansi sebesar 0,001 lebih kecil dari $\alpha=5 \%(0,05)$. Karena $t_{\text {hitung }}>\mathrm{t}_{\text {tabel, }}$ maka $\mathrm{H}_{\mathrm{o}}$ ditolak dan $\mathrm{H}_{\mathrm{a}}$ diterima. Dengan demikian $\mathrm{X} 2$ berpengaruh positif dan signifikan secara parsial terhadap kinerja pegawai.

Berdasarkan hasil koefisien regresi yang diperoleh pada Tabel 2. maka persamaan regresi yang memperlihatkan hubungan antar variabel bebas terhadap variabel terikat yang dapat ditulis sebagai berikut:

$$
Y=11,082+0,535 X_{1}+0,666 X_{2}
$$

Persamaan regresi linear berganda tersebut menerangkan bahwa, apabila terjadi peningkatan komitmen organisasi satu satuan, maka kinerja pegawai akan meningkat sebesar 0,535. Sedangkan apabila terjadi peningkatan skor pemberdayaan sebesar satu satuan, maka kinerja pegawai akan meningkat sebesar 0,666. Selain itu juga, variabel yang dominan berpengaruh terhadap kinerja pegawai adalah variabel komitmen organisasi karena memiliki nilai koefisien regresi yang besar dari variabel pemberdayaan.

Uji $\mathrm{F}$ dilakukan untuk mengetahui tingkat signifikansi pengaruh variabel komitmen organisasi dan pemberdayaan secara bersamaan terhadap kinerja pegawai. Untuk menguji hipotesis pengaruh variabel independen secara simultan terhadap variabel dependen yaitu dengan cara membanding nilai $\mathrm{F}_{\text {hitung }}$ dengan nilai yang ada pada $\mathrm{F}$ tabel, dengan ketentuan sebagai berikut: Jika $F_{\text {hitung }}>F_{\text {tabel }}$, maka $\mathrm{H}_{0}$ di tolak; dan Jika $F_{\text {hitung }}<F_{\text {tabel }}$, maka $\mathrm{H}_{1}$ di tolak. Hasil uji $\mathrm{F}$ dapat dilihat pada tabel di bawah ini

Tabel 3. Hasil Pengujian Hipotesis Secara Simultan ANOVA ${ }^{a}$

\begin{tabular}{|c|c|c|c|c|c|}
\hline Model & Sum of Squares & $d f$ & Mean Square & $F$ & Sig. \\
\hline Regression & 1412.636 & 2 & 706.318 & 27.814 & $.000^{b}$ \\
\hline Residual & 2056.924 & 81 & 25.394 & & \\
\hline Total & 3469.560 & 83 & & & \\
\hline
\end{tabular}

a. Dependent Variable: Kinerja Pegawai

b. Predictors: (Constant), pemberdayaan, Komitmen organisasi

Sumber: Output SPSS Tahun 2021

Berdasarkan pada Tabel 3 di atas, memperlihatkan nilai $\mathrm{F}$ hitung sebesar 27,814 pada tingkat signifikan 0,000. Dengan menggunakan tingkat kepercayaan 95\%, $\alpha=5 \%$, df1 (jumlah variabel -1$)$ atau $3-1=2$, df $2(n-k-1)$ atau $84-2-1=81$, sehingga hasil diperoeh $F_{\text {tabel }}$ sebesar $=3,109$. Hasil perhitungan menunjukkan nilai $F_{\text {hitung }}$ lebih besar dari $F_{\text {tabel }}$ $(27,814>3,109)$ atau nilai signifikansi lebih kecil $(0,000)$ dari nilai alpha $(0.05)$, maka keputusan yang diambil adalah menolak $\mathrm{H}_{0}$ dan menerima $\mathrm{H}_{\mathrm{a}}$. Hal ini berarti, komitmen organisasi dan pemberdayaan secara simultan berpengaruh positif dan signifikan terhadap kinerja pegawai RSUD Dr. H. Chasan Boesoirie Ternate.

Tabel 4.Model Summary

\begin{tabular}{|c|c|r|r|}
\hline $\boldsymbol{R}$ & $\boldsymbol{R}$ Square & Adjusted $\boldsymbol{R}$ Square & Std. Error of the Estimate \\
\hline $.638^{\mathrm{a}}$ & .407 & .393 & 5.03926 \\
\hline
\end{tabular}

Sumber: Data diolah 2021

Berdasarkan tabel 4. (model summary) di atas, diperoleh nilai R sebesar 0,638 atau 63,80\%, yang berarti bahwa terdapat hubungan positif antara komitmen organisasi dan pemberdayaan dengan Kinerja pegawai.. Hubungan antar variabel tersebut berada kategori kuat, sebagaimana pendapat Sugiyono (2007) bahwa rentang skor 0,60 - 0,79 berarti hubungan yang kuat sebesar 
63,80\%. Sementara itu, nilai determinasi $R^{2}$ ( $R$ squared)sebesar 0,407 yang berartibahwa, presentase sumbangan pengaruh variabel komitmen organisasi (X1) dan pemberdayaan (X2) terhadap Kinerja pegawai sebesar 39,30\%, dan sisanya 60,70\% dipengaruhi oleh variabel lain yang tidak diteliti dalam penelitian ini.

\section{Pembahasan}

Hasil pengujian hipotesis pertama menunjukan bahwa komitmen organisasi berpengaruh positif dan signifikan terhadap kinerja pegawai. hasil ini menunjukan bahwa komitmen organisasi mampu memberikan kontribusi berarti terhadap kinerja pegawai. Hasil tanggapan responden terhadap variabel komitmen organisasi sebelumnya menunjukan bahwa secara keseluruhan umumnya berada pada kategori tinggi, karena nilai rata-rata skornya berada pada kategori setuju. Hal tersebut mengandung arti bahwa indikator-indikator komitmen organisasi yang terdiri dari: 1) Perasaan adanya keterikatan, 2) Perasaan memiliki pada organisasi, 3) Perasaan untung, 4) Perasaan kurang alternatif, 5) Perasaan berhutang pada organisasi, 6) Perasaan mempunyai kesamaan terhadap nilai-nilai organisasi. Pada dasarnya Komitmen Organisasi merupakan loyalitas dan keterikatan karyawan dengan organisasi (Daft, 2006).

Hasil penelitian ini juga sejalan dengan Pathan, Natsir, \& Adda (2016) yang menunjukan bahwa komitmen organisasional yang meliputi: komitmen afektif (Affective Commitment), komitmen kontinyu (Continuance commitment), (Normative Commitment) berpengaruh positif terhadap kinerja karyawan. Definisi ini melihat kompetensi sebagai suatu kekuatan yang dimiliki secara personal untuk memberikan kontribusi kepada organisasi. Hal ini berarti bahwa, hasil kerja pegawai RSUD Dr. Chasan Boesoirie Ternate secara langsung dipengaruhi oleh komitmen organisasi pegawainya.

Selain hal di atas, berdasarkan distribusi tanggapan responden terhadap variabel komitmen organisasi seluruh item berada dalam kategori setuju. Meskipun demikian, terdapat beberapa hal yang perlu diperhatikan dan dilakukan oleh pegawai, karena masih ada pegawai yang menyatakan tidak setuju terkait dengan: 1). masa karier saya di dalam organisasi ini, 2). bersemangat menjaga reputasi organisasi ini, 3). berpartisipasi dalam meningkatkan etos kerja organisasi, 4). pegawai ikut terpanggil memperbaiki mutu Organisasi, 5). selalu mempertimbangkan, jika ingin keluar dari organisasi ini. 6). kehidupan pegawai akan terganggu apabila memutuskan untuk meninggalkan organisasi sekarang, 7). pegawai merasa sulit untuk mengaplikasikan keahlian yang dimiliki saat ini di organisasi lain, 8). berkewajiban untuk membantu rekan kerja dalam menyelesaikan tugas.

Berdasarkan uraian-uraian di atas, menunjukan bahwa komitmen organisasi memiliki pengaruh positif dan signifikan terhadap kinerja pegawai. Hasil peneitian ini relevan dengan hasil penelitian sebelumnya yang menunjukan bahwa komitmen organisasi yang terdiri dari: komitmen berjelanjutan (continuance commitment), dan komitmen normatif (normative commitment) berpengaruh terhadap kinerja pegawai (Latief et al., 2019; Paramita et al., 2020; dan Ramli \& Siti, 2020).

Hasil pengujian hipotesis kedua menunjukan bahwa pemberdayaan berpengaruh positif dan signifikan terhadap kinerja pegawai di RSUD Dr. H. Chasan Boesoirie Ternate. Hasil ini menunjukan bahwa pemberdayaan yang baik akan memberikan kontribusi positif dan signifikan terhadap kinerja pegawai. Hasil pengujian ini berdasarkan pada hasil pengujian secara parsial yang menunjukan nilai t hitung lebih besar dari nilai t tabel dan nilai signifikan yang lebih kecil nilai alpha.

Hasil tanggapan responden terhadap variabel pemberdayaan sebelumnya menunjukan bahwa secara keseluruhan berada pada kategori tinggi, karena nilai rata-rata skornya berada pada kategori setuju. Hal tersebut mengandung arti bahwa indikator-indikator pemberdayaan 


\section{Irawati, Adnan Rajak, Zulkifli, Rahmat Sabuhari}

yang terdiri dari: 1) Kebebasan, 2) Independensi, 3) Kewenangan dalam melakukan aktivitas kerja, 4) Perhatian terhadap pekerjaan, 5) Perhatian terhadap kepercayaan, 6) Kemampuan yang dimiliki, 7) Keahlian yang dimiliki, 8) keputusan, 9) Tindakan mampu meningkatkan kinerja pegawai. Menurut Fauzi (2019) bahwa, pemberdayaan mempengaruhi kinerja karyawan, dan secara simultan terdapat pengaruh yang positif dan signifikan antara variabel kepribadian dan Pemberdayaan terhadap kinerja karyawan.

Selain hal di atas, berdasarkan distribusi tanggapan responden terhadap variable pemberdayaan seluruh item berada dalam kategori setuju. Meskipun demikian, terdapat beberapa hal yang perlu diperhatikan dan dilakukan oleh pegawai RSUD Dr. H. Chasan Boesoirie Ternate, karena masih ada pegawai yang menyatakan tidak setuju yaitu: 1). kebebasan (otonomi) untuk menyelesaikan suatu pekerjaan tanpa pengawasan pimpinan secara ketat, 2). independensi (keterkaitan) antara pekerjaan saya dengan pegawailainnya, 3). Saya merasa adanya kewenangan penuh atas penyelesaian pekerjaan yang terjadi di tempat Kerja, 4). Pimpinan (atasan langsung) memberikan motivasi kepada pegawai untuk memperhatikan pekerjaan secara kontinyu dan sistimatis, 5). Pimpinan (atasan langsung) mendorong karyawan untuk percaya atas keberhasilan pekerjaan individual akan mempengaruhi kinerja organisasi, 6). Saya merasa keahlian yang dikembangkan oleh Organisasi memberikan peluang kepada karyawan dalam menghadapi tantangan pekerjaan yang baru, 7). Karyawan selalu dilibatkan dalam pengambilan keputusan sesuai dengan kebutuhan organisasi. Deskripsi tersebut merupakan hasil analisis berdasarkan tanggapan responden atau pegawai yang masih menunjukan adanya pernyataan tidak setuju, walaupun secara keseluruhan nilai rata-rata variabel komitmen organisasi berada pada kategori setuju.

Berdasarkan uraian-uraian di atas, maka dapat disimpulkan bahwa pemberdayaan memiliki pengaruh positif dan signifikan terhadap kinerja pegawai dapat dibuktikan dalam penelitian dan dapat mengkonfirmasi penelitian sebelumnya yang dilakukan oleh Chauhan (2017); Nwachukwu (2019); dan Fauzi (2019).

\section{Kesimpulan}

Berdasarkan hasil analisis data dan pembahasan yang telah diuraikan sebelumnya, maka dapat ditarik kesimpulan sebagai berikut; Pertama, bahwa komitmen organisasi secara langsung berpengaruh positif dan signifikan terhadap kinerja pegawai. Kedua, bahwa pemberdayaan berpengaruh positif dan signifikan terhadap kinerja pegawai. Ketiga, bahwa komitmen organisasi dan pemberdayaan berpengaruh yang positif dan signifikan secara simultan terhadap kinerja pegawai di RSUD Dr. H. Chasan Boesoirie Ternate.

\section{Daftar Pustaka}

Adiftiya, J. (2014). Pengaruh Komitmen Organisasi Terhadap Kinerja Karyawan Pada PT. Bukit Makmur Mandiri Utama Site Kideco Jaya Agung Batu Kajang Kabupaten Paser. EJournal Ilmu Administrasi Bisnis, 2(4).

Bose, I. (2018). Employee Empowerment And Employee Performance: An Empirical Study On Selected Banks In UEA. Journal of Applied Management and Investment, 7(2).

Campbel, J. (1990). Modeling The Performance Prediction Problem In Industrial and Organizational Psychology. In Cambridge, MA: In Handbook of Insdustrial and Organizational Psychology, ed $M P$ Dunnette and L M Hugh, Balckwell.

Cascio, W. F. (2006). Managing Human Resources: Productivity, Quality of Life, Profits. (Tenth Edit). New York: McGraw-Hill Irwin.

Chauhan, A. S. (2017). Does Empowering Employee Enhance Employee Performance? Prestige International Journal of Management \& IT-Sanchayan, 6(1).

Daft, L. R. (2006). Management. Jakarta: Salemba Empat. 
Fauzi, H. (2019). Pengaruh Keperibadian Dan Pemberdayaan Terhadap Kinerja Karyawan PT. Astra International Tbk-Daihatsu Medan. Skripsi, Program Studi Manajemen Fakultas Ekonomi Universitas Medan.

George, J. M., \& Jones, G. R. (2005). Understanding and Managing Organizational Behavior. New Jersey: Pearson Education, Inc.

Irfandi, Yonathan, P., \& Dirga, L. A. (2017). Pengaruh Kompensasi Finansial Dan Pemberdayaan Terhadap Kinerja Karyawan. Journal.Feb.Unmul.Ac.Id, 4(2).

Ivancevich, J. M., Robert, K., \& Matteson, M. T. (2011). Organizational Behavior and Management (Ninth Edit). New York: McGraw-Hill Componies Inc.

Kumar, M. S., \& Sajld, S. A. (2019). A Study of Employee Empowermentand Its Impact on Employee'sPerformance in Private Hospitals atVellore, Vellore District. International Journal of Commerce, 7(3).

Latief, A., Syardiansah, \& Muhammad, S. (2019). Pengaruh Komitmen Organisasi dan Kepuasan Kerja terhadap Kinerja Karyawan Badan Penyelenggara Jaminan Sosial Kesehatan. Public Admnistration Journal, 9(1).

Luthans, F. (2012). Perilaku Organisasi (Pertama). Yogyakarta: The McGraw-Hill Companies, Inc. Indonesia Publisher: CV. Andi Offset.

Manery, B. R., Lengkong, V. P. K., \& Saerang, R. T. (2018). Pengaruh Komitmen Organisasi dan Budaya Organisasi Terhadap Kinerja Pegawai di BKDPSDA di Kabupaten Halmahera Utara. Jurnal EMBA, 6(4).

Mangkunegara, A. A. A. P. (2009). Evaluasi Kinerja Sumber Daya Manusia. Bandung: PT Refika Aditama.

McShane, \& Glinow, V. (2008). Organizational Behavior (Fourt Edit). New York: McGraw Hill Irwin, Campanies, Inc.

Melizawati. (2015). Pengaruh Komitmen Organisasi Terhadap Kinerja Karyawan (Studi Kasus Pada PT. Indotirta Abadi Di Gempol Pasuruan. Jurnal Akuntansi, Fakutas Ekonomi Universitas Negeri Surabaya, 3(3).

Meyerson, G., \& Dewenttinck, B. (2012). Effect of Empowerment on Employees Performance. Advanced Research in Economic and Management Sciences (AREMS), 2.

Nwachukwu, O. P. (2019). The Employee Empowerment and Job Performance in Thebanking Sector (A Case Study of Diamond Bank PLC, Nigeria). Thesis, Human Resources Management University Bangkok, Thailand. Retrieved from https://e-research.siam.edu/wpcontent/uploads/2019/empowerment

Paramita, Erna, Prihatin, Lumbanraja, \& Yeni, A. (2020). The Influence of Organizational Culture and Organizational Commitment on Employee Performance and Job Satisfaction as a Moderating Variable at PT. Bank Mandiri (Persero), Tbk. International Journal of Research and Review, 7(3).

Pathan, R. D., Natsir, S., \& Adda, H. W. (2016). Analisis Pengaruh Komitmen Afektif, Komitmen Berkelanjutan dan Komitmen Normatif Terhadap Kinerja Karyawan pada PT Radio Nebula Nada di Kota Palu. Jurnal Ilmu Manajemen Universitas Tadulako, 2(2), 175-186.

Ramli, A. H., \& Siti, M. (2020). Organisational Commitment And Job Performaance in Banking Industry. International Journal of Scientific \& Technology Research, 9(3).

Riduwan, \& Kuncoro, E. A. (2014). Analisis Jalur (Cetakan Ke). Bandung: Alfabeta.

Sabuhari, R., \& Irawanto, D. W. (2020). The Importance of Flexibility of Human Resources and Employee Performance on Logistic Industry in the Eastern part of Indonesian Region: A Literature Review. In Proceedings of the 23rd Asian Forum of Business Education(AFBE 2019) (Vol. 144, pp. 205-210). Bali. Indonesia: Atlantis Press. https://doi.org/10.2991/aebmr.k.200606.034

Susanti, \& Palupiningdyah. (2016). Pengaruh Kepuasan Kerja dan Komitmen Organisasi Terhadap Kinerja Karyawan Dengan Turnover Intention sebagai Variabel Intervening. Management Analysis Journal, 5(1). 